ЦИВІЛЬНЕ ПРАВО І ЦИВІЛЬНИЙ ПРОЦЕС; СІМЕЙНЕ ПРАВО;

МІЖНАРОДНЕ ПРИВАТНЕ ПРАВО

УДК 347.441

DOI https://doi.org/10.32844/2618-1258.2021.3.4

БОГАТОВ Д.Е., МЕЛЕШЕВ І.С., ПРИХОДЬКО В.С.

ДО ПИТАННЯ ПРО ПРОБЛЕМИ ЕЛЕКТРОННОЇ ФОРМИ ДОГОВОРУ КУПІВЛІ-ПРОДАЖУ

\title{
ON THE ISSUE OF PROBLEMS OF THE ELECTRONIC FORM OF THE PURCHASE AGREEMENT
}

\begin{abstract}
Стаття присвячена дослідженню актуальних проблем існування та укладення електронних договорів купівлі-продажу, що набувають значної популярності у зв'язку з розвитком наукового-технічного прогресу.

Автори зазначають, що договір купівлі-продажу є одним із найбільш розповсюджених видів договорів, що існують в цивільному праві не тільки України, а й інших держав світу. Посилаючись на Закон України «Про електронну комерцію», автори цитують, що електронний договір - домовленість двох або більше сторін, спрямована на встановлення, зміну або припинення цивільних прав та обов'язків, оформлена в електронній формі.
\end{abstract}

Першою проблемою, розглянутою у статті, стає певна колізія щодо оферти, що існує між двома базовими законами, що регулюють дане питання, а саме: відповідно до норм Цивільного кодексу України пропозиції, адресовані невизначеному колу осіб, є запрошенням робити пропозиції укласти договір, якщо інше не вказано в рекламі або інших пропозиціях. Водночас у Законі України «Про електрону комерцію» йдеться про те, що оферта може бути зроблена такими способами, як відправка комерційного електронного повідомлення, розміщення за допомогою мережі Інтернет або в інших подібних системах інформації і телекомунікації.

Особливу увагу у статті звернено на необхідність підписання електронного договору купівлі-продажу за допомогою електронного підпису, адже досить часто в Інтернеті важко ідентифікувати реальну особу, а інколи анонімність або використання чужого імені може призвести до збитків та інших наслідків матеріального та нематеріального характеру.

У статті наголошується, що наявні в законодавстві приписи можуть не виконуватися, а процедура отримання електронного цифрового підпису бути взагалі не відомою для більшості громадян. Це свідчить про необхідність руху в напрямку реформування та модернізації як інституту електронного підпису, так і електронних договорів.

Крім цього, у статті наведені й інші можливі складності щодо електронного договору купівлі-продажу, вони стосуються проблеми місця укладання договору,

\footnotetext{
(C) БОГАТОВ Д.Е. - студент III курсу (Інститут прокуратури та кримінальної юстиції Національного юридичного університету імені Ярослава Мудрого)

(C) МЄЛСШЕВ І.С. - студент III курсу (Інститут прокуратури та кримінальної юстиції Національного юридичного університету імені Ярослава Мудрого)

( С ПРИХОДЬКО В.С. - студентка III курсу (Інститут прокуратури та кримінальної юстиції Національного юридичного університету імені Ярослава Мудрого)
} 
доказування факту укладання договору, незмінності його даних та захисту від проникнення та злому конфіденційної інформації.

Ключові слова: договір купівлі-продажу, договірне право, оферта і акиепта, прогалини в законодавстві, електронний договір, електронний цифровий підпис.

The article is devoted to the study of current problems of existence and conclusion of electronic contracts of sale, which are gaining considerable popularity due to the development of scientific and technological progress.

The authors note that the contract of sale is one of the most common types of contracts that exist in the civil law not only of Ukraine but also of other countries. Referring to the Law of Ukraine "On E-Commerce", the authors cite that an electronic contract is an agreement between two or more parties aimed at establishing, changing or terminating civil rights and obligations, executed in electronic form.

The first problem considered in the article is a certain conflict over the offer that exists between the two basic laws governing this issue, namely: in accordance with the Civil Code of Ukraine, proposals addressed to an indefinite number of persons are an invitation to make a contract if other is not specified in advertising or other offers. At the same time, the Law of Ukraine "On Electronic Commerce" states that the offer may be made in such ways as sending a commercial electronic message, placement via the Internet or other similar information and telecommunications systems.

The article pays special attention to the need to sign an electronic contract of sale with an electronic signature, because it is often difficult to identify a real person on the Internet, and sometimes anonymity or use of another's name can lead to losses and other tangible and intangible consequences.

The article emphasizes that the provisions of the legislation may not be complied with, and the procedure for obtaining an electronic digital signature may not be known to most citizens. This indicates the need to move towards reforming and modernizing both the institution of electronic signatures and electronic contracts.

In addition, the article presents other possible difficulties with the electronic contract of sale, they relate to the problem of the place of the contract, proving the fact of the contract, the invariability of its data and protection against intrusion and hacking of confidential information.

Key words: contract of sale, contract law, offer and acceptance, gaps in legislation, electronic contract, electronic digital signature.

Вступ. На сучасному етапі розвитку науково-технічного прогресу діджиталізація захопила чи не всі сфери суспільного життя. На фоні побудови «держави в смартфоні» як форми зв'язку громадянина та держави все більше й більше починають розвиватися приватноправові відносини в мережі Інтернет, зокрема йдеться про укладення договорів. На перший план виходить зручність та швидкість використання таких інформаційно-телекомунікаційних систем, однак існує і ряд проблем під час укладення таких договорів, які можна прослідкувати на прикладі електронного договору купівлі-продажу.

Чи не кожна особа хоча б раз замовляла щось в Інтернеті, тим самим укладаючи такий договір, однак постає питання про момент укладення договору та про наявність всіх необхідних реквізитів, зокрема електронного цифрового підпису. У зв'язку із цим актуально та доцільно розглянути частину проблем, що наявні у сфері укладання електронних договорів купівлі-продажу.

Постановка завдання. Метою роботи $є$ аналіз сучасного стану функціонування електронної форми договору купівлі-продажу, розгляд спірних позицій представників доктрини на наявні проблеми та певні колізії у правовому регулюванні названого питання.

Стан дослідження проблеми. Питанню електронних договорів, а зокрема електронних договорів купівлі-продажу присвячена значна кількість доктринальних праць таких науковців, як: Г.В. Гоголіна, Ю.В. Єльчанінов, А.А. Митник, Ю.О. Патинка, І.В. Стаднік, Т.А. Чернова та інші.

Результати дослідження. Договір купівлі-продажу, безспірно, є одним із найрозповсюдженіших видів договорів, що існують у цивільному праві не тільки України, а й інших держав світу. Пов'язано це з тим, що уявити життя без покупок різного масштабу майже неможливо, 
хоча б через те, що навіть для задоволення базових потреб людини необхідні певні речі, які в еру комерції легко придбати, що і є підтвердженням висловленої тези.

Перш за все, варто розпочати 3 дослідження поняття «електронний договір». Таке визначення міститься у вітчизняному законодавстві, у п. 5 ст. 3 Законі України «Про електронну комерцію» автори цитують, що електронний договір - домовленість двох або більше сторін, спрямована на встановлення, зміну або припинення цивільних прав та обов'язків, оформлена в електронній формі [1]. Тотожність юридичної сили електронних правочинів та правочинів, укладених в іншій формі, передбаченій законодавством, встановлена законом (ст. 205 ЦК України, ст. 5 Закону України Про електронну комерцію») [1;2].

Щоб договір дійсно визначався як «домовленість», необхідно висловлення оферти та отримання акцепти. Стосовно цього питання К.В. Ципищук вказує на вже висловлену в доктрині позицію стосовно колізії щодо оферти електронного договору купівлі продажу, адже, як стверджує авторка, відповідно до ч. 2 ст. 641 пропозиції, адресовані невизначеному колу осіб, $\epsilon$ запрошенням робити пропозиції укласти договір, якщо інше не вказано в рекламі або інших пропозиціях. Водночас у ч. 4 ст. 11 Закону України «Про електронну комерцію» йдеться про те, що оферта може бути зроблена такими способами як відправка комерційного електронного повідомлення, розміщення за допомогою мережі Інтернет або в інших подібних системах інформації і телекомунікації [3, с. 137]. Як вбачається, дійсно існує певна колізія, яка повинна бути усунута законодавцем задля того, аби не перешкоджати існуванню інститутів електронної комерції.

Вже перші кроки в дослідженні дають нам зрозуміти, що договір купівлі-продажу через Інтернет не такий однозначний, як могло здаватися. Г.В. Гоголіна достатньо влучно звертає увагу на типові або характерні ознаки електронного договору купівлі-продажу, стверджуючи, що договірний характер та застосування інформаційно-телекомунікаційних систем вказує на його дистанційність. Науковиця також наголошує, що звернення такого договору до невизначеного кола осіб із неможливістю надати переваги будь-кому з них без застосування спеціальних заходів робить його публічним. На думку авторки, форма вчинення електронного правочину має бути визначена законодавцем остаточно та наведена ії дефініція для уникнення правових непорозумінь, які неодмінно виникають під час тлумачення актів національного законодавства, що посилаються то на письмову, то на електронну форму [4, с. 160].

Варто погодитись з А.А. Митник та Ю.В. Сльчаніновим стосовно того, що використання новітніх інтернет-технологій у підприємницькій, торговій сферах у багатьох аспектах полегшує життя як продавців, так і покупців (наприклад, швидке онлайн-замовлення будь-якого товару чи послуги в будь-який час за наявності лише смартфона та можливість з’єднатися з мережею Інтернет). Проте через відсутність чіткого законодавчого регулювання суспільних відносин, які виникають під час укладання договору купівлі-продажу з використанням мережі Інтернет, виникають нові проблеми [5, с. 102].

Важливим є також момент укладення договору або його підписання. Згідно із частиною 1 статті 12 Закону України «Про електронну комерцію» моментом підписання електронного договору є використання:

1) електронного підпису або електронного цифрового підпису відповідно до Закону України «Про електронний цифровий підпис», за умови використання коштів електронного цифрового підпису всіма сторонами електронної правової угоди;

2) електронного підпису одноразовим ідентифікатором, визначеними цим Законом;

3) аналога власноручного підпису (факсимільного відтворення підпису за допомогою засобів механічного або іншого копіювання, іншого аналога власноручного підпису) при письмовій згоді сторін, у якій мають міститися зразки відповідних аналогів власноручних підписів [1].

Відповідно до пункту 12 частини 1 статті 1 Закону України «Про електронні довірчі послуги» електронний підпис - електронні дані, які додаються підписувачем до інших електронних даних або логічно з ними пов'язуються і використовуються ним як підпис. Кваліфікований електронний підпис має таку саму юридичну силу, як і власноручний підпис, та має презумпцію його відповідності власноручному підпису [6].

Існування електронного підпису $є$ необхідною та виправданою умовою укладення досліджуваного договору, адже в мережі Інтернет важко ідентифікувати особу, яка може використовувати ніки, псевдоніми або й використовувати чуже ім'я. На таку проблему звертає увагу і Ю.О. Патинка, адже, як пише автор, Інтернет-мережі допускають отримання доступу до наявних у ній інформаційних ресурсів під псевдонімом або взагалі анонімно. Анонімність поведінки в мережі Інтернет є причиною складності ідентифікації суб'єктів. Хоча учасник цих правовідносин 
(продавець) і повинен вказати свої дані, він може вказувати своє ім'я (псевдонім), проте складно перевірити його достовірність і простежити: дійсно дії здійснюються однією особою під одним і тим же ідентифікатором або ж під одним ідентифікатором діють кілька осіб [7, с. 54].

Безперечно, є зрозумілим той факт, що сьогодні велика частина договорів купівлі-продажу через Інтернет не оформлюється відповідним чином, а певна частина населення в силу відсутності знань у галузі права зовсім не обізнана в питаннях укладення електронних договорів. Як зазначають Т.А. Чернова, I.В. Стаднік, одним із питань, що потребують нормативного вирішення у цій сфері, є організація роботи центрів сертифікації ключів, які мають надавати послуги цифрового підпису. Окрім цього, науковці наголошують, що для остаточного масового використання електронного цифрового підпису в Україні необхідно прийняти певну кількість нормативно-правових актів щодо: національних стандартів, вимог до засобів електронного цифрового підпису, форматів даних, які для цього використовуються. Усе це допоможе покращити функціонування інституту електронного цифрового підпису та вдосконалити процес електронного документообігу [8, с. 66].

Загалом, можна виділити й переваги саме електронної форми договору купівлі-продажу, серед них - можливість укладання дистанційно, швидкість, зручність, така форма є певним проявом переходу в «державу смартфонів», тобто еру, в якій всі питання вирішуються з використанням мережі Інтернет. Водночас проблеми, що існують у даній сфері, гальмують розвиток цього перспективного інституту, що потребує поступової та виваженої політики з боку законодавця щодо усунення колізій та лакун.

Можна говорити й про інші, не названі в роботі проблеми, зокрема: складність встановлення місця укладення договору; проблема доказування самого факту укладення договору, а також незмінність і збереження даних, зафіксованих у даному договорі; проблема встановлення факту того, що він походить від контрагента; а також наявна можливість проникнення в конфіденційну інформацію про умови договору, злому.

Висновки. Отже, під електронним договором купівлі-продажу можна розуміти стандартний у цивілістичному розумінні договір, який укладається за допомогою мережу Інтернет. У той час як багато експертів відзначають комфортність та легкість укладання такого договору (електронного договору купівлі-продажу), не слід оминати увагою й наявні проблеми, серед яких - складнощі, що пов'язані з офертою та акцептом, з'ясуванням особистості контрагентів, використанням електронного підпису. Деякі питання можуть вирішуватися за аналогією з нормами цивільного права, однак для того щоб надалі е-договори мали більше переваг, ніж недоліків, законодавцю варто провести складну та своєчасну роботу в напрямку покращення вже наявних механізмів укладання таких договорів.

\section{Список використаних джерел:}

1. Закон України «Про електронну комерцію» від 03.09.2015 № 675-VIII. URL : https:// zakon.rada.gov.ua/laws/show/675-19\#top (дата звернення: 01.08.2021).

2. Цивільний кодекс України від 16.01.2003 № 435-IV. URL : https://zakon.rada.gov.ua/laws/ show/435-15\#Text (дата звернення: 01.08.2021).

3. Ципищук К.В. Деякі особливості укладення електронних договорів купівлі-продажу. Юридичний науковий електронний журнал. 2021. № 3. С. 136-138.

4. Гоголіна Г.В. Місце електронного договору купівлі-продажу в системі договорів торгівлі. Часопис Київського університету права. 2017. № 3. С. 158-161.

5. Митник А.А., Сльчанінов Ю.В. Правові аспекти договірних відносин у мережі Інтернет. Право і суспільство. 2019. № 5. С. 99-106.

6. Закон України «Про електронні довірчі послуги» від 05.10.2017 № 2155-VIII URL : https://zakon.rada.gov.ua/laws/show/2155-19\#Техt (дата звернення: 01.08.2021).

7. Патинка Ю.О. Правові проблеми укладення договору купівлі-продажу з використанням мережі Інтернет. Актуальні проблеми вітчизняної юриспрудениіï. 2016. № 3. С. 53-56.

8. Чернова T.А., Стаднік І.В. Електронний цифровий підпис як реквізит договору купівлі-продажу в мережі Інтернет. Вісник студентського наукового товариства Донецького наиіонального університету. 2016. № 8. С. 63-66. 